\title{
ABD ve AB Tarafindan Uygulanan Ticaret Politikası Önlemlerinin Türk Çelik Sektörüne Etkileri
}

\author{
Selahattin Armağan VURDU ${ }^{1}$
}

$\overline{O Z Z}$

Sanayi üretiminin ana girdilerinden olan çelik ürünlerinin tüketimi ülkelerin gelişmişlikleri ile paralellikler teşkil etmektedir. Inşaat, otomotiv, beyaz eşya, enerji, makina vb. birçok sanayi sektöründe kullanılan çelik ürünleri temel girdi durumundadır ve bu sebeple ekonomik açıdan stratejik sektörler arasında gösterilmektedir. 21. yüzyllda sivı çelik üretimi gelişmiş ülkelerde düşüş eğilimi göstermektedir, gelişmekte olan ülkelerde ise artış eğilimindedir. Başta $A B$ ve $A B D$ olmak üzere, gelişmiş ülkeler de üretimlerindeki bu düşüş eğiliminin önüne geçmek ve iç pazarlarını korumak için ticaret politikası önlemlerine başvurmaktadırlar. Böylelikle çelik ithalatlarını kontrol altına alırken, üretim açısından mevcut durumu koruma veya iyileştirme beklentisindedirler. Nitekim dünyada en fazla korumacılık önlemi uygulanan sektörlerden biri de yine çelik sektörüdür. Korumacılık önlemleri kapsamında vergi velya kota uygulamaları ön plana çıkmaktadır. Türkiye sıvı çelik üretiminde ve çelik ihracatında dünyanın önemli ülkeleri arasında yer almakta olup söz konusu önlemelere sıklıkla maruz kalmaktadır. Özellikle 2015-2020 yllları arasında ABD, geçmiş yıllarda Türkiye'nin en fazla çelik ihracatı yaptı̆̆ uyguladı̆̆ Section 232 kapsamındaki \%25 verginin Türkiye aleyhine iki katına çıkartılması nedeniyle bu süre zarfinda Türkiye'nin ABD'ye çelik ihracatı durma noktasına gelmiş; Türkiye için uygulanan ilave \%25 verginin kaldırılmasın takiben ihracat hacimleri normalleşme sürecine girmiştir ancak vergi öncesi dönemdeki seviyelere ulaşamamuştır. Diğer yandan AB'de uygulanan kotalar sebebiyle de Türkiye'nin bu bölgeye ihracatı sınırlandırllmış ve bu durum da istatistiklere olumsuz olarak yansımıştır. Türk çelik sektörü bu dönemde pazar çeşitlendirmesini gerçekleştirebilmiştir. Türkiye'nin ihracatında önemli yere sahip geleneksel pazarları olarak nitelendirilen $A B D$ ve AB pazarlarında yaşanan daralma, alternatif pazarlar olarak görülen Güneydoğu Asya, Batı Afrika ve Latin Amerika pazarları ile telafi edilmeye çalışılmıştır. Bu çalışmada Türkiye'nin 2015-2020 yılları arasında gerçekleştirdiği çelik ihracatı incelenmekte, ABD ve AB'nin ticaret politikası önlemlerinin, kendi iç pazarlarındaki üretim, ihracat ve ithalatına etkisi analiz edilmektedir.

Anahtar kelimeler: çelik, korumacılık, ticaret politikası, section 232, ihracat, vergi, kota

\section{The effects of the trade policy measures implemented by the USA and the EU on the Turkish steel industry}

\begin{abstract}
Consumption of steel products, one of the main inputs of industrial production, is in parallel with the development level of countries. The steel products used in many industrial sectors such as construction, automotive, white goods, energy, machinery, etc. are the main inputs, and therefore are among the strategic sectors economically. In the 21st century, liquid steel production shows a downward trend in developed countries, while it is on an increasing trend in developing countries. Developed countries, especially the EU and the USA, also resort to trade policy measures to prevent this decline in their production and to protect their domestic markets. Thus, while controlling steel imports, they expect to maintain or improve the current situation in terms of production. As a matter of fact, one of the sectors where protectionist measures are applied the most in the world is the steel sector. Tax and/or quota applications come to the fore within the scope of protectionist measures. Turkey is among the important countries of the world in liquid steel production and steel exports and is frequently exposed to these measures. While the USA has been the country with the highest steel exports from Turkey in the past years between 2015 and 2020, Turkey's steel exports to the USA have come to a standstill during this period due to the doubling of the 25\% tax under Section 232 applied by the US government against Turkey in recent years. Following the
\end{abstract}

\footnotetext{
${ }^{1}$ Dr. Öğr. Gör., İstanbul Ticaret Üniversitesi, savurdu@gmail.com, ORCID: 0000-0002-5836-876X

Makale Geliş Tarihi: 25.05.2021, Makale Kabul Tarihi: 24.06.2021
}

ARAŞTIRMA MAKALESİ (Research Article)

*Bu makale intihal programında taranmış ve en az iki hakem incelemesinden geçmiştir. (This article has been scanned via a plagiarism software and reviewed by at least two referees).

Doi: https://doi.org/10.51524/uhusbad.940334 
removal of the additional 25\% tax for Turkey, figures of Turkey's export to USA entered a normalization process, but has not yet reached the pre-tax levels. On the other hand, Turkey's exports to the EU have been restricted due to the quotas applied in this region and this situation has reflected negatively in the statistics. The Turkish steel industry has been able to achieve the market diversification in this period. The shrinkage in the US and EU markets, which are considered Turkey's traditional markets with important weight in Turkey's exports, has been tried to be compensated through Southeast Asia, West Africa and Latin America, which are seen as alternative markets. In this study, Turkey's steel exports between 2015-2020 are examined, and the effects of US and EU's trade policy measures on production, exports and imports in their domestic markets are analyzed.

Key words: steel, protectionism, trade policy, section 232, export, tax, quota 


\section{Giriş}

1850 yıllarında İngiltere'de başlayıp Avrupa'ya yayılan ikinci sanayi devrimi ile teknolojinin hakim olduğu, üretimde makine kullanımına geçilmesiyle üretim teknolojisinde köklü bir dönüşüm başlatılmıştır. İkinci sanayi devrimi ile dönüşüm İngiltere'de tekstil, çelik ve demir yolu sektörlerinde başlamıştır (Aksoy, 2016: 33). Sanayi sektörlerinin gelişimi ile birlikte inşaat, otomotiv, beyaz eşya, enerji, makina vb. birçok sektörde temel girdi olarak çelik ürünleri kullanılmaktadır ve bu sebeple çelik sektörü ekonomik açıdan stratejik sektörler arasında gösterilmektedir. Çelik sektörü gelişimi açısından değerlendirildiğinde, 20. yüzyılda daha çok gelişmiş ülkeler ile özdeşleşen çelik üretimi, 21. yüzyılda gelişmiş ülkelerde düşüş eğilimi göstermekte iken gelişmekte olan ülkelerde ise artış eğilimindedir.

Dünya ham çelik üretimi 2020 yılında bir önceki yıla oranla \% 0,9 azalış ile 1 milyar 864 milyon tona gerilemiştir. Dünya çelik üretiminin \% 56,5'ini temsil eden Çin ise 2020 y1lında \% 5,2 oranında büyümüştür. Çin'in dışında kalan 811 milyon tonluk çelik üretiminde ise geçtiğimiz yıla oranla \% 7,7 oranında daralma gerçekleşmiştir. 2020 yılında küresel çelik üretiminde ilk 15 ülke arasında yer alan ülkelerden sadece Çin, Rusya, Türkiye, İran ve Vietnam'ın üretimlerinde artışlar görülürken; en büyük üreticiler arasında yer alan Avrupa Birliği ve ABD’nin üretimlerinde ise çift haneli düşüşler kaydedilmiştir (World Steel Association, 2021a).

2020 y1lında pandemi nedeniyle üretim açısından genel daralma yaşayan çelik sektörü, küresel olarak artan korumacilık trendinin de etkisiyle ticarette de daralma yaşamıştır. 2020 yılının 9 aylık verilerine göre, dünyanın en çok çelik ihracatı gerçekleştiren ilk 10 ülkesinin tamamında çelik ihracatı düşüşler göstermiştir. Dünyanın en büyük çelik ihracatçısı olan Çin, 2015 yılında 127 milyon tonluk çelik ihracatı ile kırdığı rekorun ardından ihracatta her yıl azalış göstermeye devam etmiştir (trademap.org, 2021). 2020 y1lında Çin ile ilgili ticaret verileri eksik olmak ile birlikte ihracatındaki düşüş trendinin devam etmiş olduğu bilinmektedir.

Üretimlerinde artıs gösteren ülkelerin ortak özellikleri gelișmekte olan ülkeler olmaları ve üretimlerinin bir bölümünü ihracata yöneltmeleridir. Üretimlerinde düşüş gösteren bölge ve/veya ülkelerin ortak özellikleri ise gelişmiş ülkeler olmaları ve çeliğe olan taleplerinin bir bölümünü ithalat ile karşılamak durumunda kalmalarıdır. Başta dünyanın en büyük iki ekonomisi ve aynı zamanda en büyük iki çelik ithalatçısı konumundaki Avrupa Birliği ve ABD olmak üzere, gelişmiş ülkeler üretimlerindeki bu düşüş eğiliminin önüne geçmek ve iç pazarlarını korumak için ticaret politikası önlemlerine başvurmaktadırlar. Böylelikle çelik ithalatlarını kontrol altına alırken, üretim açısından mevcut durumu koruma veya iyileştirme çabasındadırlar.

\section{Ticaret Politikası Önlemi Kavramı}

Başta $A B D$ ve $A B$ olmak üzere, gelişmiş ülkeler tarafindan iç pazarlarını koruma amacıyla son dönemde sıklıkla başvurulan 'Ticaret Politikası Önlemleri' yaygın olarak 3 şekilde uygulanmaktadır; bunlar antidamping, korunma önlemi, telafi edici vergi (anti-sübvansiyon) olarak gruplanmaktadır (Aslan ve Yaman, 2020: 243). Damping, bir ürünün normal değerinin altında bir fiyatla, diğer bir ifadeyle, ihracatçı ülkede tüketime konu aynı veya benzer bir ürünün karşılaştırılabilir fiyatından daha düşük bir fiyatla ihraç edilmesi şeklinde tanımlanmaktadır. Damping temelde ulusal piyasa ile uluslararası piyasa arasında ortaya çıkan fiyat farklılaşmasıdır. Dolayısıyla yerli üreticinin fiyatına kıyasla düşük olan her ihraç fiyatı damping tanımının kapsamına girmemektedir. Korunma önlemleri ise bir malın benzer veya doğrudan rakip mallar üreten yerli üreticiler üzerinde ciddi zarar veya ciddi zarar tehdidi oluşturacak şekilde artan miktar ve şartlarda ithal edilmesi halinde, bu zarar veya zarar tehdidini ortadan kaldırmak üzere, söz konusu zarar veya zarar tehdidiyle sınırlı ve geçici olmak kaydıyla alınabilmektedir. Korunma önlemleri, diğer ticaret politikası önlemlerinden (anti-damping ve telafi edici vergi) farklı olarak; firma bazlı değil, ülke bazlı ve belirli ülkelerden gerçekleştirilen ithalata değil, tüm ithalata uygulanmaktadır. Telafi edici vergi, menşe veya ihracatçı ülkenin fayda sağlayan, doğrudan veya dolaylı mali katkısı veya Gümrük Tarifeleri ve Ticaret Genel Anlaşması (GATT) 1994'ün 16. maddesi çerçevesinde herhangi bir gelir veya fiyat desteği sübvansiyon olarak kabul edilir. Sübvansiyona konu olan ithalata karşı önlem alınabilmesi için sübvansiyonun, Sübvansiyonlar ve Telafi Edici Tedbirler Anlaşması'na göre yasaklanmış veya önlem alınabilir sübvansiyonlardan olması gerekir. Sübvansiyon soruşturması sonucu 
sübvansiyonun, yerli üretim dalında maddi zararın ve her ikisi arasında illiyet bağının tespit edilmesi neticesinde sübvansiyona karşı alınabilmektedir (T.C. Ekonomi Bakanlığı İhracat Gelen Müdürlüğü Pazara Giriş ve Uluslararası İlişkiler Daire Başkanlığı, 2015; T.C. Ticaret Bakanlığı, t.y.).

Bunlar haricinde ve gümrük tarifeleri dışında uluslararası mal ve hizmet alımlarının serbest ticaret koşulları altında gerçekleşmesini engelleyici her türlü araç ve politika tarife dışı engel olarak adlandırılmaktadır.

ABD tarafından 20 Nisan 2017 tarihinde çelik ithalatının ABD ulusal güvenliği üzerinde bir tehdit oluşturup-oluşturmadığının incelenmesi için, 1962 yılına ait 'Trade Expansion Act' in 232. bölümü kapsamında bir soruşturma başlatılmıştır. Section 232 olarak bilinen bu soruşturmada çelik ürünleri ithalatına \%25 vergi getirilmiş ve 23 Mart 2018 tarihi itibariyle yürürlüğe koyulmuştur. Bu süreçte Kanada, Meksika, Avustralya, Arjantin, Güney Kore, Brezilya ve Avrupa Birliği, söz konusu önlemlerden 1 Mayıs 2018 tarihine kadar muaf tutulmuştur (Çelik İhracatçıları Birliği, 2021a).

ABD'nin Section 232 soruşturmasının ardından, diğer ülkeler de ABD'den doğabilecek ticaret sapmalarının önüne geçebilmek ve iç pazarlarını koruyabilmek için çeşitli önlemler yürürlüğe koymuşlardır. Bunlardan en kapsamlı olanı Avrupa Birliği tarafından uygulanmıştır. Avrupa Komisyonu tarafından 26 Mart 2018 tarihinde 28 ürün grubunda yer alan çelik ithalatına karşı korunma önlemi soruşturması başlatılmıştır. Bu kapsamda ilgili ürün gruplarının ithalatına global ve ülke tarife kotaları ve kota aşımı sonrasında \% 25 ilave vergi şeklinde önlem uygulanmıştır. Ürün grupları daha sonra revize edilmiş ve 5 ürün grubunda önemli ithalat artışı olmaması sebebiyle 23 ürün grubu olarak önlem devam etmiştir. Buna ilaveten Türkiye için 9 ürün grubunda ithalat pay1 \%3'ün altında kaldığ1 gerekçisiyle muafiyet tanınmıştır (Çelik İhracatçıları Birliği, 2021a).

\section{3. Çelik Sektörü Tanımı}

Çelik sektörünün kapsadığı ürünler bakımından uluslararası kabul gören ortak bir tanımı bulunmamaktadır. Ancak çelik sektörü; sıvı çelik üretimi, sıvı çelikten üretilen yarı mamuller, yarı mamullerden üretilen nihai mamuller ve nihai mamuller kullanılarak üretilen uç ürünler olarak kategorilere ayrılabilir. Dünya çelik ticaretine konu olan çelik ürünleri Gümrük Tarife İstatistik Pozisyonu (GTIP) kodlarına göre kategorize edildiğinde, çelik sektörü Demir ve Çelik (72. fasıl) ile Demir ve Çelikten Eşyalar (73. fasıl) olarak tanımlanmıştır. Türkiye'nin sektörler bazında ihracatında ilişkin resmi açıklamalar yapılırken, çelik ihracatı açıklaması için Çelik İhracatçıları Birliği iştigal sahası kapsamı kullanılmaktadır. Bu kapsam 72. faslın tamamı (GTIP 7202 hariç) ile 73. fasılda GTiP 73017318 arasındaki kodları içermektedir. Ülkelerin çelik sektörlerini korumak amacıyla açıkladıkları önlemler bu sebeple Türkiye'deki çelik tanımından farklılıklar gösterebilmektedir.

ABD'nin çelik sektörünü korumak amacıyla başlattı̆̆ Section 232 ticaret politikası önleminde yer alan ürünler, Türkiye'nin Çelik İhracatçıları Birliği iştigal sahası kapsamında ihraç ettiği ürünlerin 5 yıllık toplamının \%92,7'sine karşı1ık gelmektedir. Avrupa Birliği'nin Türkiye'ye uyguladığı korunma önleminde yer alan ürünler ise, Türkiye'nin Çelik İhracatçıları Birliği iştigal sahası kapsamında ihraç ettiği ürünlerin 5 yıllık toplamının \%87,2'sine karş1lık gelmektedir. Avrupa Birliği'nin Türkiye'ye uyguladığ1 korunma önlemi ürünlerinde Türkiye'nin ihracatı, ABD Section 232 ürünlerinde Türkiye'nin ihracatının 5 ylllık toplamının \%94,1'ine karş1lık gelmektedir. 
Tablo 1. Türkiye’nin Çelik İhracatının Ticaret Politikası Önlemleri Kapsamında Analizi

\begin{tabular}{|c|c|c|c|c|c|c|}
\hline & 2015 & 2016 & 2017 & 2018 & 2019 & 2020 \\
\hline ÇİB İştigal Sahası Ürünleri (Bin Ton) & 16.128 & 16.509 & 17.724 & 21.313 & 21.157 & 20.465 \\
\hline ABD Section 232 Ürünleri (Bin Ton) & 14.895 & 15.368 & 16.460 & 19.883 & 19.552 & 18.814 \\
\hline ÇİB içindeki payı \% & $92,40 \%$ & $93,10 \%$ & $92,90 \%$ & $93,30 \%$ & $92,40 \%$ & $91,90 \%$ \\
\hline $\begin{array}{l}\text { AB'nin Türkiye'ye uyguladığı KÖ } \\
\text { Ürünleri (Bin Ton) }\end{array}$ & 14.355 & 14.855 & 15.318 & 18.621 & 17.940 & 17.723 \\
\hline ÇİB içindeki payı \% & $89,00 \%$ & $90,00 \%$ & $86,40 \%$ & $87,40 \%$ & $84,80 \%$ & $86,60 \%$ \\
\hline $\begin{array}{l}\text { AB'nin Türkiye'ye uyguladı̆̆ } 1 \text { KÖ'nin } \\
\text { ABD Section } 232 \text { içindeki Pay } 1 \%\end{array}$ & $96,40 \%$ & $96,70 \%$ & $93,10 \%$ & $93,70 \%$ & $91,80 \%$ & $94,20 \%$ \\
\hline
\end{tabular}

Kaynak: tim.org.tr verileri kullanılarak yazar tarafindan oluşturulmuştur.

\section{ABD Section 232 Soruşturmasının Çelik Sektörüne Etkileri}

ABD Ticaret Bakanlığı (DoC) Section 232 olarak bilinen düzenlemesi ile çelik ithalatının ABD ulusal güvenliğini tehdit edip etmediğinin araştırılması için 20 Nisan 2017'de bir soruşturma başlatmıştır. Section 232, Ticaret Bakanlığına ithalatın ulusal güvenliğe etkisinin araştırılması için kapsamlı bir soruşturma yürütme yetkisi vermektedir. 1962 tarihli Ticaretin genişletilmesi yasası kapsamındaki Section 232, ABD'nin 1995'te Dünya Ticaret Örgütü'ne (DTÖ) üye olmasından bu yana sadece iki kere gündeme gelmiş olup bunlardan ilki 2001 yılında demir çelik ürünleri ithalatına karşı yürütülmüştür. DoC her iki soruşturmada da ulusal güvenliğin korunması için herhangi bir kısıtlayıcı önlem alınmasına gerek olmadığına karar vermiştir. Bu mevzuat dahilinde, ulusal savunma için ne kadar yerli üretime ihtiyaç olduğuna, ulusal savunma gereksinimleri için yerli üretim kapasitesinin yeterliliğine, ulusal ekonomik refah ile ulusal güvenlik arasındaki ilişkiye dair Savunma Bakanlığı ile koordineli bir çalışma yürütülmüştür. Çalışma 2018 yılının Ocak ayında Başkan Donald Trump’a iletilmiş, aynı yılın Şubat ayında basın-kamuoyuna tanıtılmış, 8 Mart 2018 tarihinde Başkan tarafindan imzalanmış ve 23 Mart 2018 tarihinde yürürlüğe girmiştir.

Section 232 ile gelen ek \%25'lik vergiden Meksika ve Kanada, NAFTA anlaşması görüşmeleri kapsamında ilk aşamada muaf tutulmuştur. 31 Mayıs 2018 tarihli karar ile Meksika ve Kanada'ya uygulanan muafiyete son verilmiştir. Aynı tarihli kararda, Avustralya, Arjantin, Brezilya ve Güney Kore'den yapılan ithalatta kota uygulamasına geçilmiştir. 21 Mayıs 2019 tarihinde alınan karar ile Meksika, Kanada ve Avustralya Section 232 soruşturmasından muaf tutulmuştur. Ağustos 2018'de Başkanlık kararı ile sadece Türkiye'den yapılan çelik ithalatına Section 232 kapsamında alınan \%25'lik ithalat vergisi \%50 seviyesine çıkarılmış, Mayıs 2019'da ise Türkiye’ye uygulanan vergi tekrar \%25 seviyesine indirilmiştir (Çelik İhracatçıları Birliği, 2021b).

Section 232 uygulamasının ABD çelik sektörüne olan etkisi incelendiğinde, 2017 yılında toplamda 34,6 milyon ton seviyesinde yer alan ithalatın, 2019 yılında \%27 düşüş ile 25,4 milyon ton seviyesine gerilediği, 2020 yılı ilk 10 aylık döneminde ise 2019 yılı aynı dönemine göre \%22,6 düşüş ile 17,4 milyon ton seviyesine gerilediği görülmektedir (dataweb.usitc.gov, 2021). İthalatta yaşanan düşüş ve 2017-2019 yıllarında gayri safi yurt içi hasılada yakalanan ortalama \%2,5'lik büyüme ile birlikte, ABD çelik sektörünü pozitif yönde etkilemiştir.

ABD’nin Başkanlık memorandumuyla Section 232 soruşturmasının başlatıldığı 2017 yılından bu yana ham çelik üretimi ve kapasite kullanım oranları (KKO) sürekli olarak artmıştır. ABD'nin iç tüketimi üretiminden fazla olup, mevcut kapasite kullanım oranıyla dahi çelik ithalatına ihtiyaç duyduğu görülmektedir. 
2016-2019 yılları arasında ABD çelik sektörünün gelişimi incelendiğinde, üretimin ve kapasite kullanım oranının sürekli artış kaydettiği görülmektedir. ABD çelik tüketiminin 2016-2018 yılları arasında artış gösterip, 2019 yılında düşüşe geçmesine rağmen, sıvı çelik üretimi ve KKO'da yaşanan artış trendi, Section 232 uygulamasının yerel çelik üreticilerini pozitif yönde etkilediğinin bir yansımasıdır.

Şekil 1. ABD’nin Ham Çelik Üretimi, Nihai Mamul Tüketimi, Kapasite Kullanım Oranı (KKO) ve Gayri Safi Yurtiçi Hasıla (GSYİH) Büyüme Oranı. (Üretim ve Tüketim Miktar: Milyon Ton, KKO:\%, GSYİH $\%$

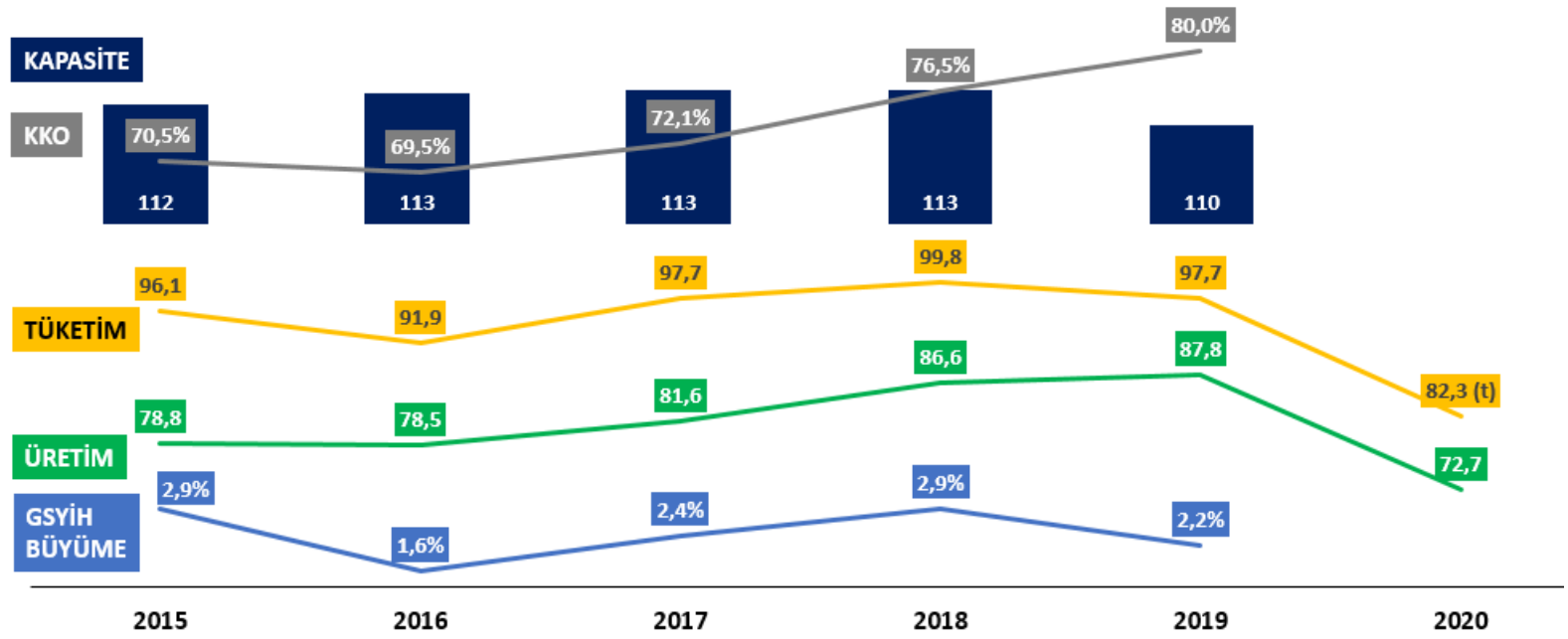

Kaynak: World Steel Association (2021a), World Steel Association (2021b), stats.oecd.org (2021), data.worldbank.org (2021) verileri kullanılarak yazar tarafindan oluşturulmuştur.

Şekil 2. ABD’nin Türkiye'den ve Çin'den Section 232 Ürünleri İthalatı (Miktar: Bin Ton)

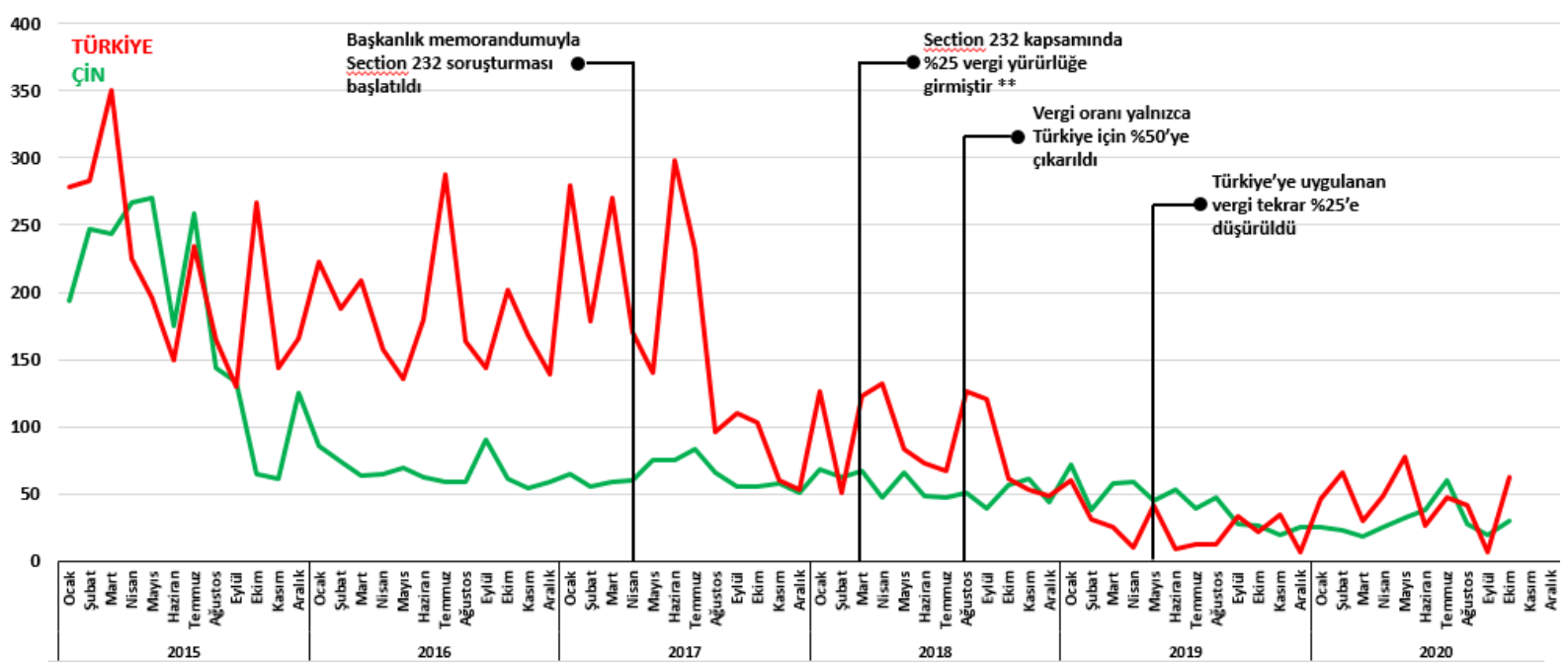

Kaynak: dataweb.usitc.gov verileri kullanılarak yazar tarafindan oluşturulmuştur.

2015 yılında devreye giren çeşitli ticaret politikası önlemleri neticesinde ABD'nin Çin'den olan çelik ithalatı 2015 y1lında 2,2 milyon ton seviyesinden, 2016 y1lında \%60'ın üzerinde düşüşle 800 bin tona gerilemiştir. Bu noktadan sonra ABD'nin Çin'i devre dışı bırakmada etkili olduğu ve Section 232'de Çin'i birincil olarak hedeflememiş olabileceği düşünülmektedir.

Section 232 öncesi Türkiye'den 2015 yılında 2,6 milyon ton, 2016 y1lında 2,2 milyon ton çelik ithalatı gerçekleştiren ABD, 2019 yılında sadece 297 bin ton ithalat (2015 yılına göre \%88, 2016 y1lına göre \%86 düşüş) gerçekleştirmiştir. 2017 y1lı Nisan ayında başlatılan Section 232 soruşturması ile 
Türkiye'den yapılan ithalatın düşüş trendine girdiği, aynı yılın Ağustos ayı itibariyle Türkiye'ye uygulanan verginin \%50'ye çıkartılmasını takiben, düşüş trendinin hızlandığı görülmektedir. 2019 Mayıs ayında Türkiye’ye uygulanan verginin tekrar $\% 25$ 'e düşürülmesi ve $\mathrm{ABD}$ iç piyasa çelik fiyatlarının yüksek seyretmesi nedeniyle 2020 Ekim ayına kadar Türkiye'den ithalatın hafif yükselişe geçtiği görülmektedir. 2020 yılının ilk yarısında yaşanan bu artışın, ABD ekonomisini etkileyen pandemi nedeniyle sürdürülemediği düşünülmektedir.

Şekil 3. ABD’nin Arjantin, Güney Kore, Brezilya'dan Section 232 Ürünleri İthalatı (Miktar: Bin Ton)

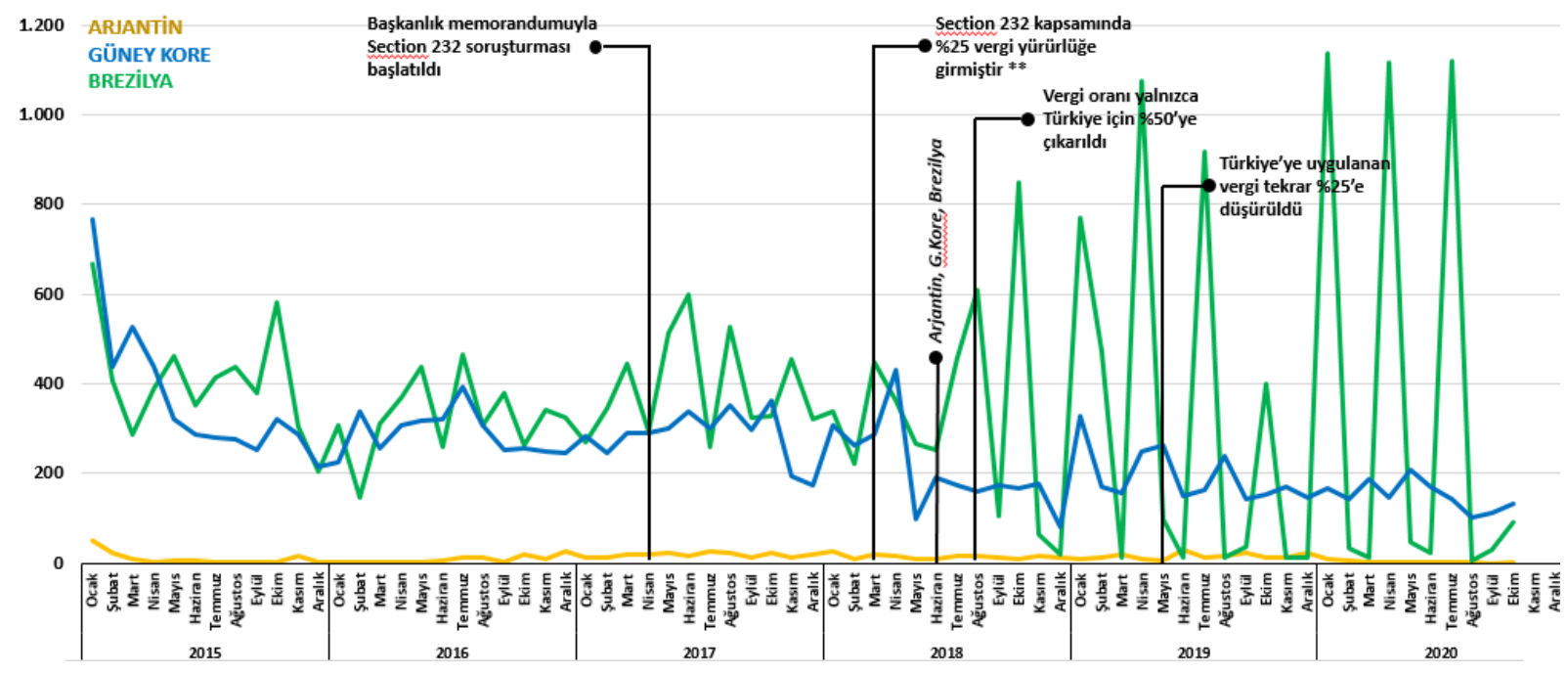

Kaynak: dataweb.usitc.gov verileri kullanılarak yazar tarafindan oluşturulmuştur.

Haziran 2018 tarihinde Arjantin, Güney Kore ve Brezilya'ya kota uygulaması başlatılmıştır. Kotalar çeyreklik kullanıldığından ithalatta çeyreklik bazda keskin değişimler görülmektedir. Kotalar, bu ülkelerden önceki dönemlerde yapılan ithalatlardan daha düşük oranlarda belirlenmiş ve kota aşımı durumunda ekstra vergi ödenmesi durumunda dahi ithalata izin verilmemiştir. Bu sebeple kota uygulamasına tabi ülkelerden yapılan ithalat Haziran 2018 öncesi döneme göre düşüş göstermiştir.

Şekil 4. ABD’nin Kanada, Meksika, Avustralya Section 232 Ürünleri İthalatı (Miktar: Bin Ton)

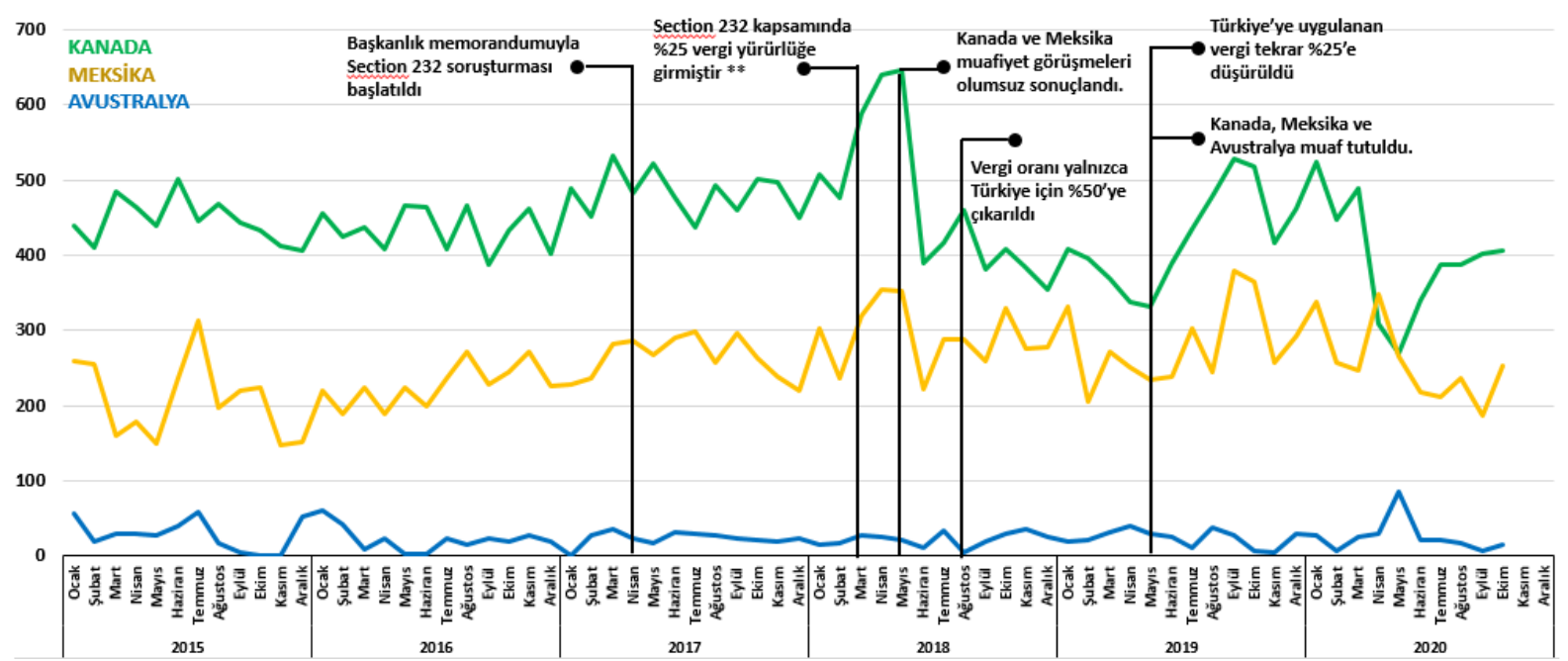

Kaynak: dataweb.usitc.gov verileri kullanılarak yazar tarafindan oluşturulmuştur.

31 Mayıs 2018 tarihinde ABD Başkanı tarafindan onaylanan karar ile Kanada, Meksika ve AB ile müzakerelerin olumlu sonuç vermediği; bu ülke menşeli ürünlerin de Section 232 önlemlerine tabi 
olmaya başlayacağı açıklanmıştır. Bu tarihten itibaren özellikle Kanada'dan yapılan ithalatta önemli düşüşler gözlenmiştir. 2019 yılının Mayıs ayı itibariyle Kanada, Meksika ve Avustralya'nın Section 232'den muaf tutulması sonrasında; üç ülkeden yapılan toplam ithalatın soruşturma öncesi dönemdeki seviyelere yaklaştığı görülmektedir. 2020 y1l ilk çeyreği sonrası ithalatta yaşanan düşüşün ABD ekonomisinde pandeminin yarattığı tahribatın etkisi olduğu düşünülmektedir.

Tablo 2. ABD’nin Section 232 Ürünlerinde Dünya'dan İthalatı (Miktar: Bin Ton)

\begin{tabular}{|c|c|c|c|c|c|c|c|c|c|c|c|}
\hline & 2015 & 2016 & 2017 & 2018 & 2019 & $\begin{array}{c}\text { 2018/19 } \\
\text { \% DEĞişiM }\end{array}$ & $\begin{array}{c}2019 \\
\text { PAY }\end{array}$ & $\begin{array}{l}2019 \\
10 \mathrm{AY}\end{array}$ & $\begin{array}{l}2020 \\
10 \mathrm{AY}\end{array}$ & $\begin{array}{c}\text { 2019/20 } \\
\text { \% DEĞişim }\end{array}$ & $\begin{array}{c}2020 \\
\text { PAY }\end{array}$ \\
\hline KANADA & 5.347 .075 & 5.214 .904 & 5.792 .933 & 5.651 .950 & 5.070 .252 & $-10,3 \%$ & $20,0 \%$ & 4.190 .346 & 3.959 .445 & $-5,5 \%$ & $22,7 \%$ \\
\hline BREZILYA & 4.879 .416 & 3.908 .928 & 4.676 .844 & 3.987 .557 & 3.828 .649 & $-4,0 \%$ & $15,1 \%$ & 3.804 .646 & 3.613 .670 & $-5,0 \%$ & $20,7 \%$ \\
\hline MEKSIKA & 2.492 .880 & 2.723 .991 & 3.164 .063 & 3.505 .684 & 3.372 .681 & $-3,8 \%$ & $13,3 \%$ & 2.824 .527 & 2.562 .653 & $-9,3 \%$ & $14,7 \%$ \\
\hline G. KORE & 4.405 .234 & 3.464 .783 & 3.418 .626 & 2.507 .436 & 2.328 .745 & $-7,1 \%$ & $9,2 \%$ & 2.013 .420 & 1.511 .227 & $-24,9 \%$ & $8,7 \%$ \\
\hline JAPONYA & 2.411 .313 & 1.950 .853 & 1.727 .357 & 1.370 .583 & 1.134 .399 & $-17,2 \%$ & $4,5 \%$ & 995.819 & 638.949 & $-35,8 \%$ & $3,7 \%$ \\
\hline ALMANYA & 1.411 .460 & 1.111 .501 & 1.382 .607 & 1.253 .660 & 967.038 & $-22,9 \%$ & $3,8 \%$ & 831.670 & 636.656 & $-23,4 \%$ & $3,7 \%$ \\
\hline TÜRKIYE & 2.588 .036 & 2.197.307 & 1.990 .293 & 1.063 .444 & 297.164 & $-72,1 \%$ & $1,2 \%$ & 256.473 & 449.578 & $75,3 \%$ & $2,6 \%$ \\
\hline TAYVAN & 1.094 .672 & 982.434 & 1.130 .009 & 975.579 & 754.164 & $-22,7 \%$ & $3,0 \%$ & 697.895 & 441.949 & -36 & $2,5 \%$ \\
\hline RUSYA & 1.925 .830 & 1.920 .984 & 2.816 .019 & 2.296 .772 & 962.305 & $-58,1 \%$ & $3,8 \%$ & 919.533 & 385.966 & $-58,0 \%$ & $2,2 \%$ \\
\hline ÇiN & 2.181 .745 & 802.024 & 758.406 & 656.274 & 507.197 & $-22,7 \%$ & $2,0 \%$ & 463.958 & 297.232 & $-35,9 \%$ & $1,7 \%$ \\
\hline HOLLANDA & 745.792 & 664.223 & 637.095 & 555.848 & 498.353 & $-10,3 \%$ & $2,0 \%$ & 386.479 & 295.937 & $-23,4 \%$ & $1,7 \%$ \\
\hline AVUSTRALYA & 336.911 & 269.304 & 281.879 & 265.499 & 283.739 & $6,9 \%$ & $1,1 \%$ & 249.443 & 254.824 & $2,2 \%$ & $1,5 \%$ \\
\hline VIETNAM & 223.306 & 849.478 & 679.073 & 1.011 .232 & 601.791 & $-40,5 \%$ & $2,4 \%$ & 564.899 & 240.756 & $-57,4 \%$ & $1,4 \%$ \\
\hline ISPANYA & 282.572 & 287.187 & 405.664 & 293.495 & 403.819 & $37,6 \%$ & $1,6 \%$ & 361.413 & 232.980 & $-35,5 \%$ & $1,3 \%$ \\
\hline BAE & 155.945 & 158.646 & 273.557 & 221.461 & 223.230 & $0,8 \%$ & $0,9 \%$ & 198.053 & 191.557 & $-3,3 \%$ & $1,1 \%$ \\
\hline DiĞERLERi & 4.952 .454 & 3.529 .570 & 5.509 .097 & 5.072 .697 & 4.159 .846 & $-18,0 \%$ & $16,4 \%$ & 3.771 .237 & 1.716 .642 & $-54,5 \%$ & $9,8 \%$ \\
\hline TOPLAM & 35.434 .641 & 30.036 .116 & 34.643 .523 & 30.689 .168 & 25.393.371 & $-17,3 \%$ & $100 \%$ & 22.529 .811 & 17.430 .023 & $-22,6 \%$ & $100 \%$ \\
\hline
\end{tabular}

Kaynak: dataweb.usitc.gov verileri kullanılarak yazar tarafindan oluşturulmuştur.

ABD'nin Section 232 ürünleri kapsamındaki ithalatı 2017 yılından sonra her yıl düşüş göstermeye devam etmiştir. 2019 yılında en fazla düşüş yaşayan ülke Türkiye, ardından Rusya, Vietnam ve Çin olmuştur.

Dünya'nın en büyük çelik ithalatçı ülkesi konumunda yer alan ABD, Section 232 uygulaması ile 20172019 yılları arasında yerli çelik üreticilerini desteklemeyi başarmıştır. ABD Çelik Birliği Başkanı (AISI) John BRETT, 5 Mart 2020 tarihinde yaptığı açıklamada şöyle demektedir:

2020 yılına optimist bir beklentiyle başladık ve Başkan Trump'un Section 232 aksiyonu için minnettarız. 2018'in ikinci çeyreğinden beri ilk defa çelik ithalatında devam eden bir düşüş neticesi aldık. 2019 yılında nihai çelik ithalatı 21 milyon tona geriledi, bu aynı zamanda 2010 yılından beri en düşük seviye ve 2003 yılından beri en düşük pazar payı. ABD'li şirketler ithalat sebebiyle kaybettikleri müşterilerini geri kazanmaktalar. Geçmişte Asya finansal krizi sonrasında ABD'de ithalatlar artmıștı. Neticesinde 33 şirket iflas etmiş ve binlerce çalışan işlerini kaybetmiști. Güvenle söyleyebilirim ki Section 232 tarifeleri ve kotaların gerekliliği her zamankinden daha da önemli bir durumdadır (ArcelorMittal, 2020).

ABD çelik sektörü temsilcileri Section 232 uygulamasının devam etmesi gerektiği yönünde görüş bildirmektedirler.

ABD'de 2020-2022 yılları arasında yapım veya plan aşamasında olan 10 milyon tona yaklașan kapasite yatırımı açıklaması yapılmıştır. Section 232 uygulaması ile desteklenen ABD çelik sektörü, iç piyasada üretim ve tüketim arasındaki makası kapatmak için yatırımlarına devam etmektedir. ABD çelik sektörünün hammadde kaynaklarına kolaylıkla erişmesi, Section 232 ve diğer korunma önlemleri sayesinde ithal ürünlerin engellenmesi sonucunda küresel fiyatların üzerinde seyreden iç piyasa fiyatları ve makroekonomik koşullara bağlı olarak çelik tüketiminin artış kaydetmesi, yerli çelik üreticilerinin karlılığını sürdürülebilir olmasını sağlamaktadır. 
Tablo 3. ABD’de Sıvı Çelik Üretim Kapasitesi Yatırım Planları (2020 ve sonrası)

\begin{tabular}{|c|c|c|c|c|c|c|}
\hline ÜLKE & ŞEHIR & FiRMA & ÜRETIM ŞEKLi & KAPASITE (BIN TON) & SON DURUM & YATIRIM BAŞLANGICI \\
\hline$A B D$ & Frostproof, Florida & Nucor Steel Florida & EAF & 317 & YAPIM AŞAMASINDA & 2020 \\
\hline ABD & Fairfield, Alabama & U.S. Steel / Fairfield Works & EAF & 1.451 & YAPIM AŞAMASINDA & 2020 \\
\hline ABD & Osceola, Arkansas & Big River Steel & EAF & 1.496 & YAPIM AŞAMASINDA & 2020 \\
\hline ABD & Baytown, Texas & JSW USA & EAF & - & PLAN AŞAMASINDA & - \\
\hline ABD & Sinton Texas & Steel Dynamics, Inc. & EAF & 2.722 & PLAN AŞAMASINDA & 2021 \\
\hline ABD & Ghent, Kentucky & Nucor & EAF & 1.271 & PLAN AŞAMASINDA & 2021 \\
\hline ABD & Brandenburg, Kentucky & Nucor & EAF & 1.088 & PLAN AŞAMASINDA & 2022 \\
\hline ABD & Delta, Ohio & North Star BlueScope Steel & EAF & 850 & PLAN AŞAMASINDA & 2022 \\
\hline
\end{tabular}

Kaynak: OECD (2020), yazar tarafından Türkçe’ye çevirilmiştir.

\section{Avrupa Birliği Korunma Önlemi Soruşturmasının Çelik Sektörüne Etkileri}

Avrupa Birliği, ABD’nin yürürlüğe koyduğu Section 232 önleminin yaratacağı etkinin kendi pazarına olumsuz yansıyacağ 1 ve iç pazara yönelik zarar tehdidi oluşturacağ 1 gerekçesiyle, belirlediği 28 çelik ürünü grubuna 26 Mart 2018 tarihinde bir Korunma Önlemi soruşturması başlatmışıtır. AB Komisyonun elindeki mevcut bilgilere göre çelik ürünleri ithalatı 2013 - 2017 döneminde 17,8 milyon tondan 29,3 milyon tona yükselmiştir. AB, nihai kararını 16 Ocak 2019'da Komisyonunda kabul etmiş 1 Şubat 2019 tarihinde Resmi Gazetesi'nde yayımlamıştır. Nihai kotalar 2 Şubat 2019 tarihinde yürürlüğe girmiştir. Nihai önlemin 'tarife kotası' biçiminde uygulanmasına karar verilmiştir. Buna göre, ABD'nin uyguladığı direk ithalat vergisi yerine, kota miktarı dolana kadar ithalat serbest şekilde sürdürülecekken kotanın dolmasından sonra yapılacak ithalatta \% 25 oranında ekstra gümrük vergisi (tarife) tatbik edilecektir. Kota seviyesi tespit edilirken 2015-2017 dönemindeki ortalama ithalat seviyesine \% 5 oranında ek ithalat miktarı eklenmiştir (Çelik İhracatçıları Birliği, 2021b).

ABD'nin uygulamış olduğu Section 232 kapsamında yer alan çelik ürünlerinin küçük bir kısmı komisyon tarafindan korunma önlemi dışında tutulmuş fakat büyük çoğunluğu korunma önlemi uygulamasına dahil edilmiştir. $\mathrm{AB}$ tarafindan Türkiye'nin dahil edildiği 18 ürün grubunda ithalatı incelendiğinde, bu ürünlerde dünyadan yapılan ithalatının tonaj bazında 2019 yılında \%13,1 azaldığı görülmektedir (ec.europa.eu/eurostat, 2020). İthalatta yaşanan bu düşüşün çelik sektörüne olan etkileri incelendiğinde ise farklı sonuçlara rastlanmıştır.

Avrupa Birliği'nin üretimi, Korunma Önlemi soruşturması başlangıcı olan 2018 yılına kadar iç tüketiminin üzerinde gerçekleşmiştir. 2018'den itibaren ise iç tüketimi üretiminin üzerine çıkmıştır. Kapasite kullanım oranları bakımından, soruşturmanın AB üretimine yıllık veriler 1şığında olumlu bir yansımasının olmadığı görülmektedir. AB'nin ham çelik üretimi 2018'den bu yana ciddi düşüş göstermiştir. 
Şekil 5. Avrupa Birliği’nin Ham Çelik Üretimi, Nihai Mamul Tüketimi, Kapasite Kullanım Oranları (KKO) ve GSYİH Büyüme Oranı. (Üretim ve Tüketim Miktar: Milyon Ton, KKO:\%, GSYİH \%)



Kaynak: World Steel Association (2021a), World Steel Association (2021b), stats.oecd.org (2021), data.worldbank.org (2021) verileri kullanılarak yazar tarafindan oluşturulmuştur.

Şekil 6. Avrupa Birliği Sıvı Çelik Üretim Kapasiteleri (Miktar: Milyon Ton)

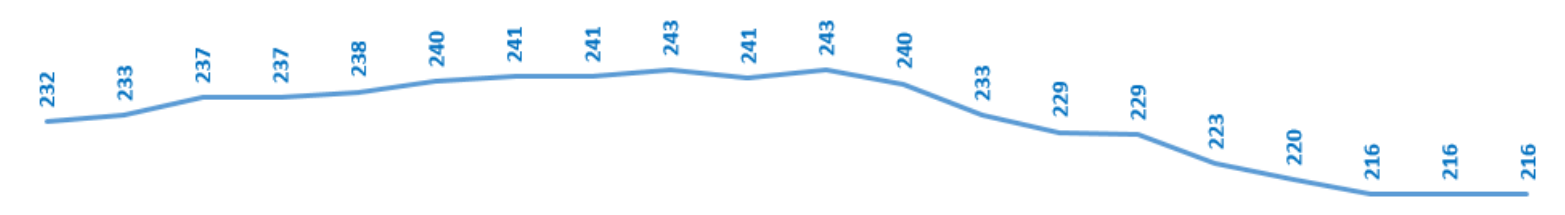

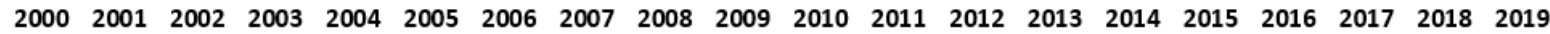

Kaynak: stats.oecd.org verileri kullanılarak yazar tarafından oluşturulmuştur.

2010 yılında gerçekleşen Yunanistan, Portekiz, İrlanda, İspanya ve Güney Kıbrıs Cumhuriyeti’nin başını çektiğgi Avrupa borç krizinin nedeniyle, AB çelik üreticileri zor bir süreçten geçmektedirler. 2010 yılından 2019 yılına kadar AB'de 27 milyon tona yakın sıvı çelik üretim kapasitesi kapatılmıştır. 20122019 yılları arasında gayri safi yurt içi hasılada ortalama \%1,4 ile düşük seviyede büyüme yakalayan $\mathrm{AB}$ ülkeleri, korunma önlemine rağmen çelik üretimini arttırmayı başaramamıştır. 2017 yılından günümüze $\mathrm{AB}$, sahip olduğu üretim kapasitesini korumayı amaçlamaktadır. 
Şekil 7. Avrupa Birliği'nin Türkiye’ye Kota Uyguladığı Ürünlerde Dünya'dan İthalatı (Miktar: Bin Ton)

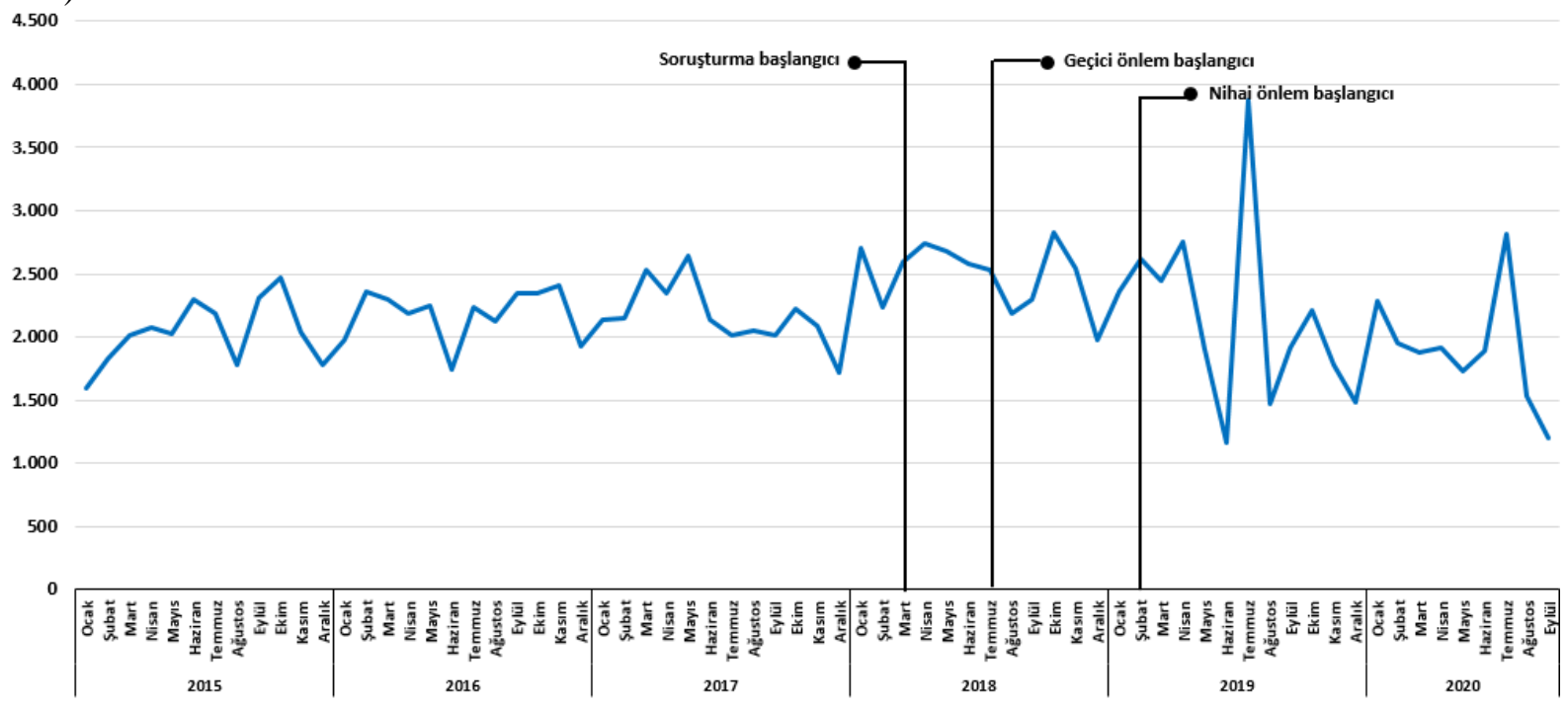

Kaynak: ec.europa.eu/eurostat verileri kullanılarak yazar tarafindan oluşturulmuştur. ${ }^{2}$

2015 yılından günümüze AB'nin Türkiye'ye kota uyguladığı ürünlerde Dünya'dan ithalat1 incelendiğinde nihai önlem başlangıcından sonra, 2019 Şubat tarihinden itibaren görülen ani değişimiler çeyreklik bazda yenilenen kotalar nedeniyle olduğu açıklanabilmektedir.

Tablo 4. AB-28’in Türkiye’ye Kota Uyguladığı Ürünlerde Dünya'dan İthalatı (Miktar: Ton)

\begin{tabular}{|c|c|c|c|c|c|c|c|}
\hline & 2015 & 2016 & 2017 & 2018 & 2019 & $\begin{array}{c}\text { 2018/19 } \\
\text { \% DEĞişím }\end{array}$ & $\begin{array}{c}2019 \\
\text { PAY }\end{array}$ \\
\hline TÜRKIYE & 2.245 .416 & 2.613.143 & 4.734 .260 & 7.371 .480 & 6.899 .779 & $-6,4 \%$ & $26,6 \%$ \\
\hline RUSYA & 3.673 .713 & 3.468 .953 & 2.447 .705 & 3.864 .677 & 3.146 .889 & $-18,6 \%$ & $12,1 \%$ \\
\hline G. KORE & 1.820 .531 & 2.151 .053 & 2.572 .519 & 2.982 .581 & 2.538 .898 & $-14,9 \%$ & $9,8 \%$ \\
\hline çin & 5.676 .536 & 4.528 .339 & 3.350 .056 & 2.819 .320 & 2.317 .064 & $-17,8 \%$ & $8,9 \%$ \\
\hline HINDISTAN & 1.174 .018 & 1.729 .956 & 3.385 .322 & 2.369 .590 & 2.099 .991 & $-11,4 \%$ & $8,1 \%$ \\
\hline TAYVAN & 404.337 & 657.918 & 1.172 .699 & 1.679 .483 & 1.286 .704 & $-23,4 \%$ & $5,0 \%$ \\
\hline UKRAYNA & 2.174 .507 & 2.303 .564 & 1.685 .276 & 1.484 .957 & 1.286 .145 & $-13,4 \%$ & $5,0 \%$ \\
\hline SIRBISTAN & 573.726 & 589.800 & 785.947 & 1.084 .132 & 1.133 .254 & $4,5 \%$ & $4,4 \%$ \\
\hline BELARUS & 1.017 .012 & 983.984 & 854.459 & 893.973 & 932.873 & $4,4 \%$ & $3,6 \%$ \\
\hline isviçRE & 929.200 & 844.377 & 903.677 & 875.400 & 668.367 & $-23,7 \%$ & $2,6 \%$ \\
\hline VIETNAM & 48.809 & 47.700 & 369.355 & 593.484 & 466.698 & $-21,4 \%$ & $1,8 \%$ \\
\hline BREZILYA & 844.981 & 1.016 .973 & 836.004 & 715.847 & 466.486 & $-34,8 \%$ & $1,8 \%$ \\
\hline NORVEÇ & 466.756 & 466.661 & 438.400 & 429.093 & 420.750 & $-1,9 \%$ & $1,6 \%$ \\
\hline MAKEDONYA & 186.133 & 230.719 & 275.077 & 316.215 & 252.887 & $-20,0 \%$ & $1,0 \%$ \\
\hline MOLDOVA & 263.444 & 188.071 & 261.715 & 357.931 & 243.278 & $-32,0 \%$ & $0,9 \%$ \\
\hline DIGĞERLERI & 2.916 .154 & 4.397 .236 & 1.972 .611 & 2.063 .627 & 1.814 .168 & $-12,1 \%$ & $7,0 \%$ \\
\hline TOPLAM & 24.415 .271 & 26.218.447 & 26.045 .081 & 29.901 .790 & 25.974.231 & $-13,1 \%$ & $100 \%$ \\
\hline
\end{tabular}

Kaynak: ec.europa.eu/eurostat verileri kullanılarak yazar tarafindan oluşturulmuştur.

${ }^{2} 2015$ Ocak - 2020 Ocak arası EU-28 verileri, 2020 Şubat sonrası BREXIT nedeniyle EU-27 verileridir. 
Tablo 5. AB-27'nin Türkiye'ye Kota Uyguladığı Ürünlerde Dünya'dan İthalatı (Miktar: Ton)

\begin{tabular}{|c|c|c|c|c|c|c|c|c|c|c|c|}
\hline & 2015 & 2016 & 2017 & 2018 & 2019 & $\begin{array}{c}\text { 2018/19 } \\
\text { \% DEĞişim }\end{array}$ & $\begin{array}{c}2019 \\
\text { PAY }\end{array}$ & $\begin{array}{l}2019 \\
10 \mathrm{AY}\end{array}$ & $\begin{array}{l}2020 \\
10 \mathrm{AY}\end{array}$ & $\begin{array}{c}\text { 2019/20 } \\
\text { \% DEĞişim }\end{array}$ & $\begin{array}{r}2020 \\
\text { PAY }\end{array}$ \\
\hline TÜRKIYE & 1.868 .319 & 2.613 .143 & 4.189.501 & 6.795 .107 & 6.326 .232 & $-6,9 \%$ & $23,7 \%$ & 5.216 .572 & 3.417 .890 & $-34,5 \%$ & $19,8 \%$ \\
\hline RUSYA & 3.472 .079 & 3.468 .953 & 2.372 .107 & 3.758 .931 & 3.032 .342 & $-19,3 \%$ & $11,3 \%$ & 2.392 .555 & 2.473 .812 & $3,4 \%$ & $14,4 \%$ \\
\hline G. KORE & 1.697 .305 & 2.151 .053 & 2.328 .939 & 2.766 .730 & 2.287 .679 & $-17,3 \%$ & $8,6 \%$ & 1.746 .223 & 1.734 .146 & $-0,7 \%$ & $10,1 \%$ \\
\hline B. KRALLIK & 2.592 .537 & 2.195 .350 & 2.657 .454 & 2.648 .310 & 2.511 .044 & $-5,2 \%$ & $9,4 \%$ & 1.874 .592 & 1.731 .178 & $-7,7 \%$ & $10,1 \%$ \\
\hline HINDISTAN & 1.135 .223 & 1.729 .956 & 3.174 .582 & 2.233 .791 & 1.987 .138 & $-11,0 \%$ & $7,4 \%$ & 1.442 .966 & 1.289 .054 & $-10,7 \%$ & $7,5 \%$ \\
\hline çin & 4.951 .815 & 4.528 .339 & 2.984 .223 & 2.741 .966 & 2.227 .388 & $-18,8 \%$ & $8,3 \%$ & 1.943 .223 & 1.028 .974 & $-47,0 \%$ & $6,0 \%$ \\
\hline UKRAYNA & 2.149 .999 & 2.303 .564 & 1.622 .263 & 1.395 .494 & 1.243 .121 & $-10,9 \%$ & $4,7 \%$ & 1.020 .948 & 792.803 & $-22,3 \%$ & $4,6 \%$ \\
\hline TAYVAN & 357.651 & 657.918 & 997.040 & 1.435 .404 & 1.161 .780 & $-19,1 \%$ & $4,3 \%$ & 872.097 & 754.838 & $-13,4 \%$ & $4,4 \%$ \\
\hline BELARUS & 1.003 .018 & 983.984 & 814.759 & 832.267 & 826.602 & $-0,7 \%$ & $3,1 \%$ & 618.480 & 667.291 & $7,9 \%$ & $3,9 \%$ \\
\hline SIRBISTAN & 573.681 & 589.800 & 785.947 & 1.084 .128 & 1.133 .254 & $4,5 \%$ & $4,2 \%$ & 833.721 & 666.388 & $-20,1 \%$ & $3,9 \%$ \\
\hline isviçRE & 882.082 & 844.377 & 885.783 & 857.655 & 655.518 & $-23,6 \%$ & $2,5 \%$ & 501.095 & 423.228 & $-15,5 \%$ & $2,5 \%$ \\
\hline BREZILYA & 820.688 & 1.016 .973 & 813.432 & 689.856 & 398.061 & $-42,3 \%$ & $1,5 \%$ & 335.900 & 311.307 & $-7,3 \%$ & $1,8 \%$ \\
\hline NORVEÇ & 432.574 & 466.661 & 417.844 & 401.858 & 395.911 & $-1,5 \%$ & $1,5 \%$ & 294.685 & 296.678 & $0,7 \%$ & $1,7 \%$ \\
\hline MOLDOVA & 263.444 & 188.071 & 261.715 & 357.931 & 243.278 & $-32,0 \%$ & $0,9 \%$ & 174.481 & 205.171 & $17,6 \%$ & $1,2 \%$ \\
\hline VIETNAM & 44.223 & 47.700 & 284.808 & 495.924 & 435.380 & $-12,2 \%$ & $1,6 \%$ & 330.332 & 200.350 & $-39,3 \%$ & $1,2 \%$ \\
\hline DiĞERLERI & 2.170 .633 & 2.432 .605 & 2.049 .243 & 2.124 .422 & 1.853 .371 & $-12,8 \%$ & $6,9 \%$ & 1.425 .924 & 1.229 .790 & $-13,8 \%$ & $7,1 \%$ \\
\hline TOPLAM & 24.415.271 & 26.218.447 & 26.639 .640 & 30.619 .773 & 26.718.098 & $-12,7 \%$ & $100 \%$ & 21.023.793 & 17.222 .895 & $-18,1 \%$ & $100 \%$ \\
\hline
\end{tabular}

Kaynak: ec.europa.eu/eurostat verileri kullanılarak yazar tarafindan oluşturulmuştur. ${ }^{3}$

AB Komisyonu tarafindan, 2016 yılında sıcak yassı ürününde Çin için hem Anti-Damping (AD) hem Telafi Edici Vergi (CVD) soruşturmaları açılmıştır, 2017 yılında nihai karar verilmiştir. 2016 yılında Rusya, İran, Ukrayna, Sırbistan ve Brezilya için ayrıca bir AD soruşturması açılmıştır, 2017 yılında nihai karar verilmiştir.

2015-2018 arasında soruşturmaların etkisiyle AB'nin Çin ve Ukrayna'dan ithalatı yarı seviyelerine inerken Türkiye, Güney Kore, Hindistan ve Tayvan'dan ithalatında ciddi artışlar yaşanmıştır. 2019 yılında tüm ülkelerden yapılan ithalatlarda çift haneli düşüşler kaydedilmiş, Türkiye'den yapılan ithalattaki düşüş ise tek haneli olmuştur. 2020 yılının ilk on aylık döneminde ise AB'nin yapmış olduğu ithalat $\% 18,1$ düşüş kaydetmiştir.

Tablo 6. Avrupa Birliği Sıvı Çelik Kapasite Yatırım Planları (2020 ve sonrası)

\begin{tabular}{|c|c|c|c|c|c|c}
\hline ÜLKE & ŞEHIR & FIRMA & ÜRETiM ȘEKLi & KAPASITE (BIN TON) & SON DURUM & YATIRIM BAŞLANGICI \\
\hline HOLLANDA & Eemshaven & Van Merksteijn International & EAF & 1.000 & PLAN AŞAMASINDA & - \\
\hline AVUSTURYA & Kapfenberg & Voestalpine & EAF & 205 & YAPIM AŞAMASINDA & 2021 \\
\hline
\end{tabular}

Kaynak: OECD (2020), yazar tarafindan Türkçe’ye çevirilmiştir.

AB ülkelerinde yakın tarihte sadece Avusturya'da yapımına başlanmış 205 bin ton kapasiteli sıvı çelik üretim tesisi yatırımı bulunmaktadır. Kısa vadede Avrupa ülkelerinde sıvı çelik kapasitesi artırımı beklenmemektedir.

Korunma önlemi ithalatın engellenmesinden ziyade kontrol altına alınmasını amaçladığı için kota uygulaması ile hedefine ulaşmıştır. $\mathrm{AB}$, iç piyasasındaki çelik tüketiminde görülen daralma nedeniyle, ithalatta yaşanan çift haneli düşüşe rağmen yerli çelik sektörünün destek talebine tam anlamıyla karşılık verememiştir. EUROFER Başkanı Geert van Poelvoorde, 26 Haziran 2019 tarihinde yaptığı açıklamada şöyle demiştir:

2018 yılında Avrupa çelik piyasası sadece \%3,3 büyüyebilirken çelik ithalatında $\% 12$ gibi rekor bir artış vardı. Avrupa Komisyonu'nun bu sorunu görerek aksiyon almıştı. Ancak korunma önlemi çelik sektörünün büyük bir bölümü için amacına ulaşmakta başarısız oldu. Korunma önlemi, AB pazarını bozan haksız ithalatı engellemeye yönelik işe yaramalı. Yapılan çelik ithalatları yerel üreticilerin hayatta kalma şanslarını riske sokuyor. Avrupa çelik sektörü, iç pazarında büyüyen dinamik bir sektör ancak çalışan sayısını ve

\footnotetext{
${ }^{3}$ Birleşik Krallık AB ülkelerine dahil değildir.
} 
üretimini kısmak zorunda kalıyor. Toplamda Avrupa Birliği Çelik sektöründe 330 bin kişi doğrudan istihdam edilmektedir (EUROFER, 2019)

\section{Section 232 ve AB Korunma Önlemi Soruşturmalarının Çelik Fiyatlarına Ektileri}

Çelik fiyatlarının; altın, gümüş, bakır, çinko, alüminyum, kalay vb. diğer emtia fiyatlarında olduğu gibi kendi başına takip edilebilen bir endeksi bulunmamaktadır. Ancak dünyada en fazla kullanılan temel girdi niteliğindeki çelik ürünleri olan inşaat çeliği ve sıcak yassı sac fiyatları çelik sektörü için gösterge niteliğinde kullanılabilmektedir. Öte yandan lojistik, yerel üretim miktarı ve ticaret politikası önlemeleri gibi gerekçelerle bu ürünlerin fiyatları da bölgelere göre değişiklik gösterebilmektedir.

Ticaret politikası önlemleri ile kısıtlanan ithalatın bir sonucu olarak bu önemleri uygulayan ülkelerin iç pazarlarında rekabet dengeleri bozulmaktadır. Bunun da fiyatlar üzerinde doğrudan arttırıcı etkileri olmaktadır. 1980'lerden itibaren ABD'de anti-damping ve telafi edici vergi gibi çeşitli önlemler ile çelik ithalatı miktar ve fiyat olarak kontrol altına alınmaya çalışılmıştır. Bu uygulamaların bir sonucu olarak ABD'de iç piyasa fiyatları diğer ülkelere göre daha yüksek seyretmektedir. Daha sonraki dönemde Avrupa Birliği de benzer uygulamalar ile iç pazarını korumaya aldığından Avrupa Birliği'nin çelik fiyatlarının da diğer ülkelerden ayrıştığını söylemek mümkündür.

Şekil 8. ABD ve Avrupa Birliği Haftalık İnşaat Çeliği Fiyatları 2015-2020 (USD/ton)

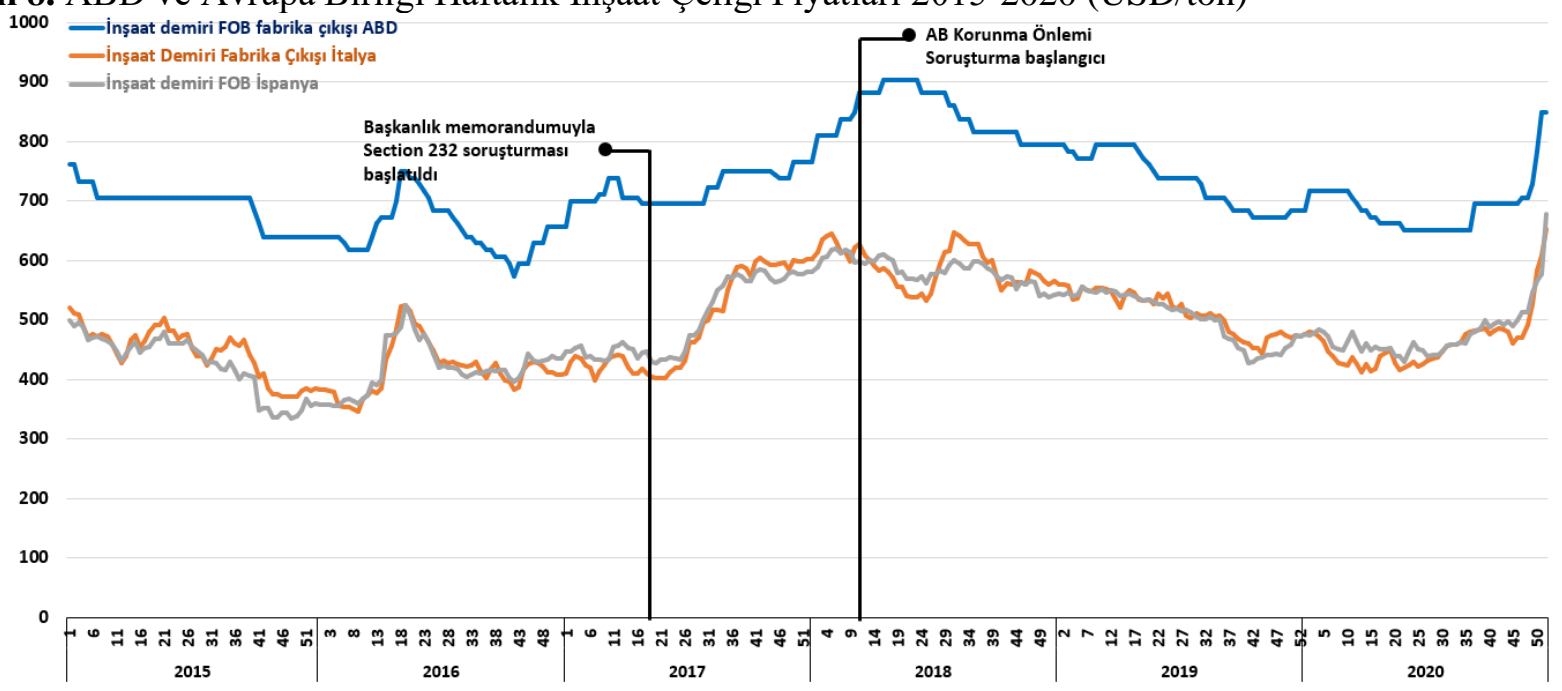

Kaynak: tr.steelorbis.com verileri kullanılarak yazar tarafindan oluşturulmuştur.

19 Nisan 2017 tarihinde Section 232 soruşturmasının başlatılmasının ardından ABD'de ortalama inşaat çeliği fiyatları hızla yükselmiştir. Aynı zamanda Section 232 soruşturmasının başlangıcından itibaren, Avrupa Birliği Korunma Önlemi soruşturmasının başlangıcına kadar Avrupa'da önemli inşaat çeliği üreticisi ülkelerden olan İtalya'da ve İspanya'da fiyat artışları yaşanmıştır. 
Şekil 9. ABD ve Avrupa Birliği Haftalık Sicak Rulo Fiyatları 2015-2020 (USD/ton)

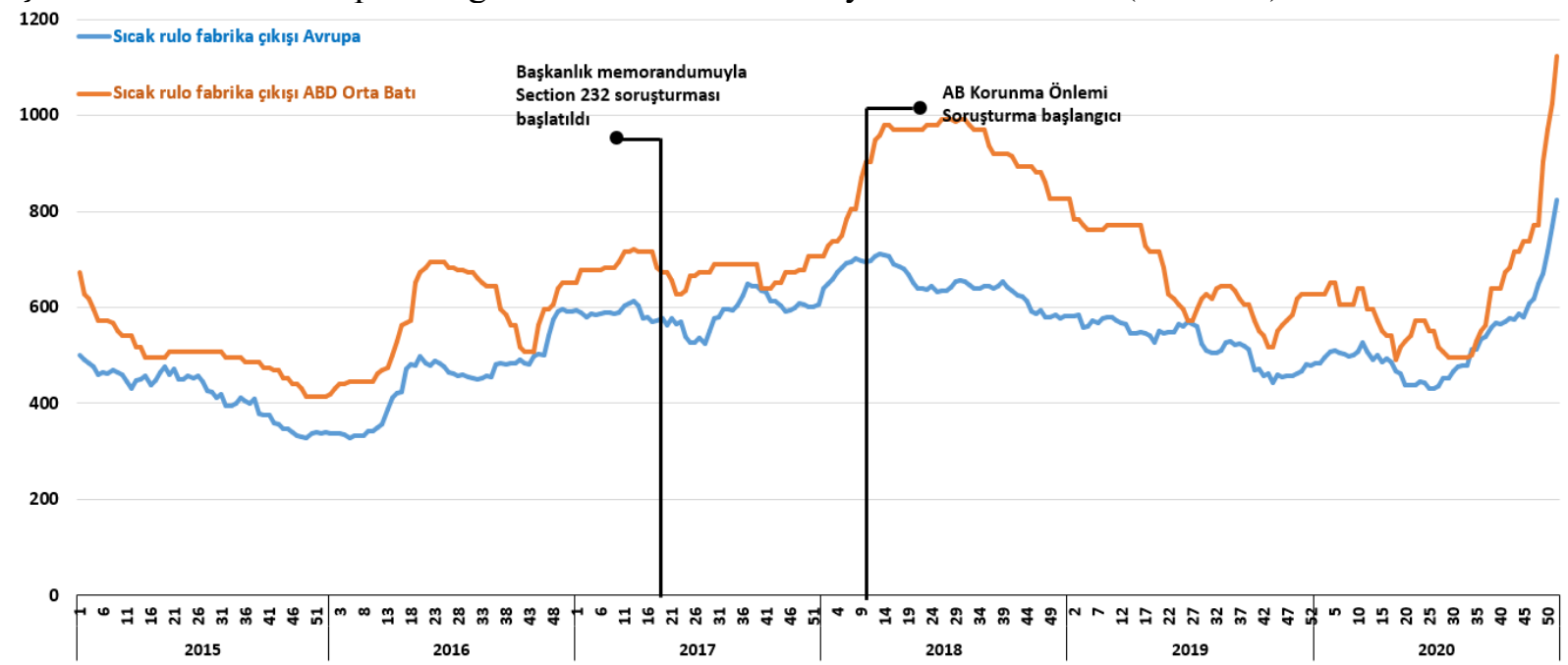

Kaynak: tr.steelorbis.com verileri kullanılarak yazar tarafindan oluşturulmuştur.

Aynı dönemlerde ABD sıcak rulo fiyatlarında da inşaat çeliğine benzer şekilde hızlı bir yükseliş gerçekleşmiştir. Bu dönemde Avrupa'da sıcak rulo fiyatlarında artış görülmüş olsa da, ABD’ye kıyasla daha düşük oranda olmuştur.

ABD Section 232'de \%25 vergi uygulamasının fiyatlara doğrudan yükseltici etkisi olduğu söylemek mümkündür. Diğer yandan Avrupa Birliği Korunma Önlemi ithalatı kotalar ile kontrol altına aldığından fiyatlarda ani yükseliş yaşamamaktadır. Bununla birlikte Avrupa Birliği'ndeki kota uygulamasında 'ilk gelen alır’ (first come first served) prensibi gerekçesiyle özellikle çeyrekler bazında açıklanan kota dönemlerinin başlarında rekabet ortamı yükseldiği için fiyatlar üzerinde dengeleyici hatta baskılayıcı bir etkisi olmaktadır.

\section{Ticaret Politikası Önlemlerinin Türk Çelik Sektörüne Etkileri}

Türkiye'nin uzun yıllardır en fazla ihracat yaptığı ve geleneksel pazarları olarak nitelendirilen pazarlar Orta Doğu, Avrupa Birliği ve Kuzey Amerika'dır. 2015-2020 döneminde Kuzey Amerika’ya olan ihracatın \%84'ü ABD'ye yapılmıştır. ABD Section 232 ve Avrupa Birliği Korunma Önlemi soruşturmasına kadar, Türkiye ağılıklı olarak ihracatını yukarıda belirtilen geleneksel pazarlara yapmakta iken, soruşturma sonrası dönemde bu pazarlarda ciddi daralmalar ile karşılaştığı gerekçesiyle alternatif pazarlara yönelmek durumunda kalmıştır (tim.org.tr, 2021).

Section 232 soruşturması başladıktan sonra Türkiye'nin ABD'ye ihracatı özellikle ABD'deki ithalatçıların gelişmelerden etkilenmesiyle düşüş yaşamış olmasına rağmen devam etmiştir. Ardından \%25 vergi yürürlüğe girdiğinde Türkiye $\mathrm{ABD}$ piyasasında eşit şartlarda rekabet ederek ihracata devam edebilmiştir. Ancak vergi Türkiye için \%50'ye çıkarıldığında Türkiye ABD pazarının dışında kalmış ve ihracatı durma noktasına gelmiştir. 
Şekil 10. Türkiye'nin ABD Section 232 Ürünlerinde ABD’ye Çelik İhracat1 2015-2020 (Miktar: Bin Ton)



Kaynak: tim.org.tr verileri kullanılarak yazar tarafindan oluşturulmuştur.

Tablo 7. Türkiye'nin ABD Section 232 Ürünlerinde Çelik İhracatı 2015-2020 (Miktar: Ton)

\begin{tabular}{|c|c|c|c|c|c|c|c|c|c|c|c|c|}
\hline & 2015 & 2016 & $\begin{array}{l}\text { 2015/16 } \\
\text { \% DĞş. }\end{array}$ & 2017 & $\begin{array}{c}\text { 2016/17 } \\
\text { \% DĞŞ }\end{array}$ & 2018 & $\begin{array}{c}\text { 2017/18 } \\
\text { \% DĞŞ }\end{array}$ & 2019 & $\begin{array}{l}\text { 2018/19 } \\
\text { \% DĞŞ }\end{array}$ & 2020 & $\begin{array}{c}\text { 2019/20 } \\
\text { \% DĞŞ }\end{array}$ & $\begin{array}{l}2020 \\
\text { PAY }\end{array}$ \\
\hline 1 AVRUPA BiRLiĞi & 2.483 .401 & 3.319 .148 & $33,7 \%$ & 5.217 .246 & $57,2 \%$ & 8.127 .930 & $55,8 \%$ & 6.650 .247 & $-18,2 \%$ & 5.706 .393 & $-14,2 \%$ & $30,3 \%$ \\
\hline 2 ORTA DOĞU & 5.038 .310 & 5.084 .874 & $0,9 \%$ & 833.738 & $-24,6 \%$ & 3.556 .573 & $-7,2 \%$ & 4.475 .825 & $25,8 \%$ & 4.488 .652 & $0,3 \%$ & $23,9 \%$ \\
\hline 3 KUZEY AFRIKA & 2.177.371 & 2.226 .241 & $2,2 \%$ & 1.410 .382 & $-36,6 \%$ & 1.473 .330 & $4,5 \%$ & 2.155 .370 & $46,3 \%$ & 1.874 .762 & $-13,0 \%$ & $10,0 \%$ \\
\hline 4 DiĞER ASYA & 115.672 & 118.623 & $2,6 \%$ & 1.142 .636 & $863,2 \%$ & 1.564 .311 & $36,9 \%$ & 1.448 .457 & $-7,4 \%$ & 1.545 .095 & $6,7 \%$ & $8,2 \%$ \\
\hline 5 ORTA VE GÜNEY AMERIKA & 1.110 .876 & 851.087 & $-23,4 \%$ & 1.154 .203 & $35,6 \%$ & 1.388 .034 & $20,3 \%$ & 1.500 .605 & $8,1 \%$ & 1.462 .357 & $-2,5 \%$ & $7,8 \%$ \\
\hline 6 BATI AFRIKA & 239.177 & 258.486 & $8,1 \%$ & 469.888 & $81,8 \%$ & 474.739 & $1,0 \%$ & 629.699 & $32,6 \%$ & 939.156 & $49,1 \%$ & $5,0 \%$ \\
\hline 7 ORT, DOĞ, GÜN A & 676.463 & 439.931 & $-35,0 \%$ & 477.497 & $8,5 \%$ & 690.201 & $44,5 \%$ & 1.078 .675 & $56,3 \%$ & 799.406 & $-25,9 \%$ & $4,2 \%$ \\
\hline 8 KUZEY AMERIKA & 2.406 .789 & 2.406 .689 & $0,0 \%$ & 2.140 .245 & $-11,1 \%$ & 1.796 .203 & $-16,1 \%$ & 495.422 & $-72,4 \%$ & 798.470 & $61,2 \%$ & $4,2 \%$ \\
\hline$-A B D$ & 2.338 .526 & 2.327.202 & $-0,5 \%$ & 1.780 .601 & $-23,5 \%$ & 1.095 .569 & $-38,5 \%$ & 248.044 & $-77,4 \%$ & 654.126 & $163,7 \%$ & $3,5 \%$ \\
\hline 9 DiĞER AVRUPA & 477.074 & 487.026 & 2 & 410.248 & $-15,8 \%$ & 476.797 & $16,2 \%$ & 753.110 & $58,0 \%$ & 781.036 & $3,7 \%$ & $4,2 \%$ \\
\hline 10 SERBEST BÖLGELER & 146.142 & 155.240 & $6,2 \%$ & 154.411 & $-0,5 \%$ & 167.211 & $8,3 \%$ & 200.239 & $19,8 \%$ & 276.497 & $38,1 \%$ & $1,5 \%$ \\
\hline 11 OKYANUSYA & 22.680 & 19.880 & $-12,3 \%$ & 46.678 & $134,8 \%$ & 166.129 & $255,9 \%$ & 163.668 & $-1,5 \%$ & 141.157 & $-13,8 \%$ & $0,8 \%$ \\
\hline DiĞER ÜLKELER & 1.133 & 1.111 & $-1,9 \%$ & 2.994 & $169,5 \%$ & 1.080 & $-63,9 \%$ & 790 & $-26,8 \%$ & 563 & $-28,8 \%$ & $0,0 \%$ \\
\hline TOPLAM & 14.895 .089 & 15.368 .336 & $3,2 \%$ & 16.460 .167 & $7,1 \%$ & 19.882 .538 & $20,8 \%$ & 19.552.110 & $-1,7 \%$ & 18.813 .544 & $-3,8 \%$ & $100,0 \%$ \\
\hline
\end{tabular}

Kaynak: tim.org.tr verileri kullanılarak yazar tarafindan oluşturulmuştur.

Söz konusu önlemlerden olumsuz etkilenen Türkiye'nin 2019 yılında ABD ve AB'ye olan ihracatındaki düşüş; hem geleneksel pazarlardan olan Orta Doğu ve Kuzey Afrika bölgelerine yapılan ihracattaki artış ile hem de alternatif pazarlar olarak nitelendirilebilecek Latin Amerika, Sahra Altı Afrika ve Diğer Avrupa bölgeleri ile telafi edilebilmiştir. Section 232 önlemi kapsamında Türkiye aleyhindeki \%50 verginin \%25'e düşürülmesi ile ABD'ye ihracatta toparlanma süreci başlamıştır. Takip eden 2020 yılında Türkiye'nin ABD'ye ihracatında yeniden artış görülürken, Orta Doğu, Latin Amerika ve Orta,Doğu,Güney Afrika bölgelerinde yavaşlama yaşanmıştır. 
Şekil 11. Türkiye’nin AB’nin Türkiye’ye Kota Uyguladığı Ürünlerde AB'ye Çelik İhracatı 2015-2020 (Miktar: Bin Ton)

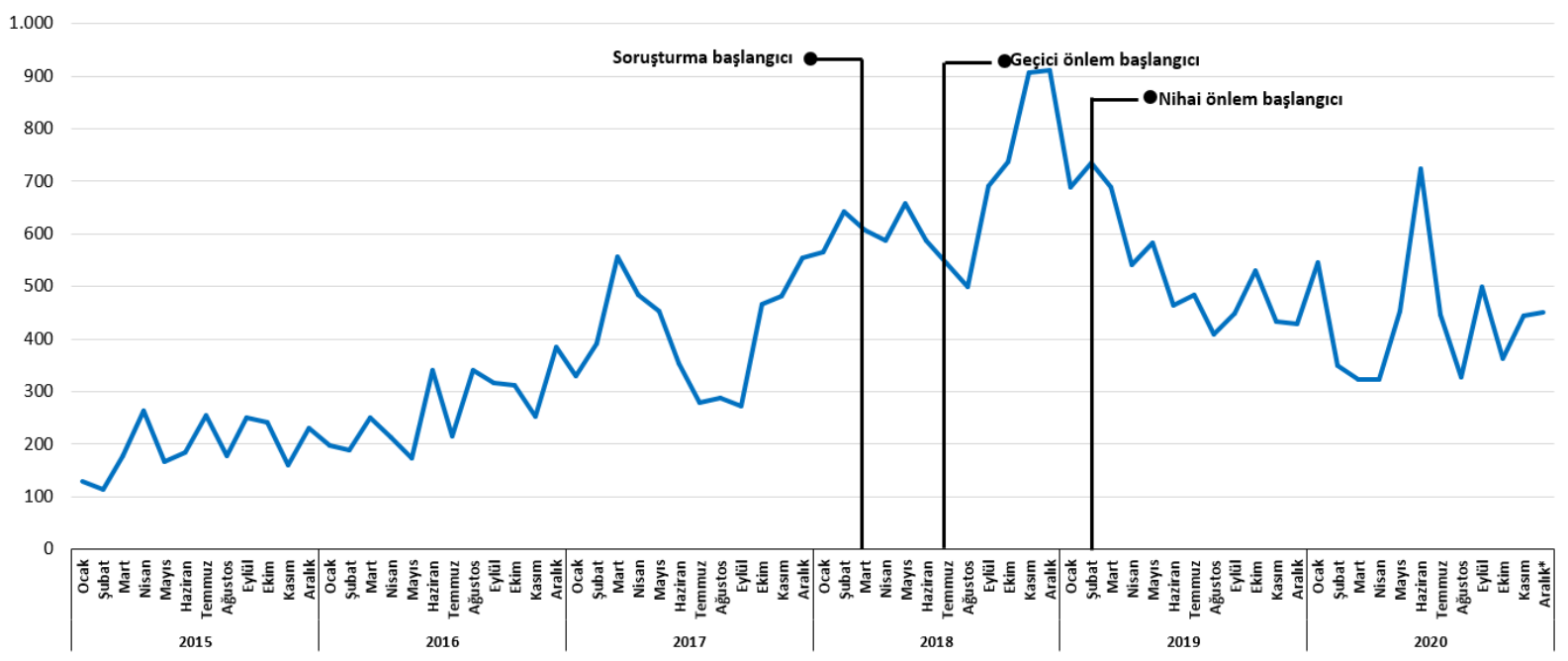

Kaynak: tim.org.tr verileri kullanılarak yazar tarafindan oluşturulmuştur.

Türkiye'nin AB'ye korunma önlemi ürünlerinde ihracatı soruşturma başlangıcına kadar istikrarlı olarak artış göstermiştir. 2018 yılında geçici önlem başlangıcından yıl sonuna kadar olan dönemde kotaları doldurmak amacıyla ihracat yeniden artış göstermiştir. 2019 Şubat itibariyle nihai önlem başlangıcı ile ihracat düşüş trendine girmiştir. 2020 Haziran ayında kotaları doldurmak için ihracatta yine kısa süreli artış yaşanmıştır.

Şekil 12. Türkiye'nin AB'nin Türkiye'ye Kota Uyguladığ 1 Ürünlerde AB'ye Çelik İhracatı 2015-2020 (Miktar: Bin Ton)

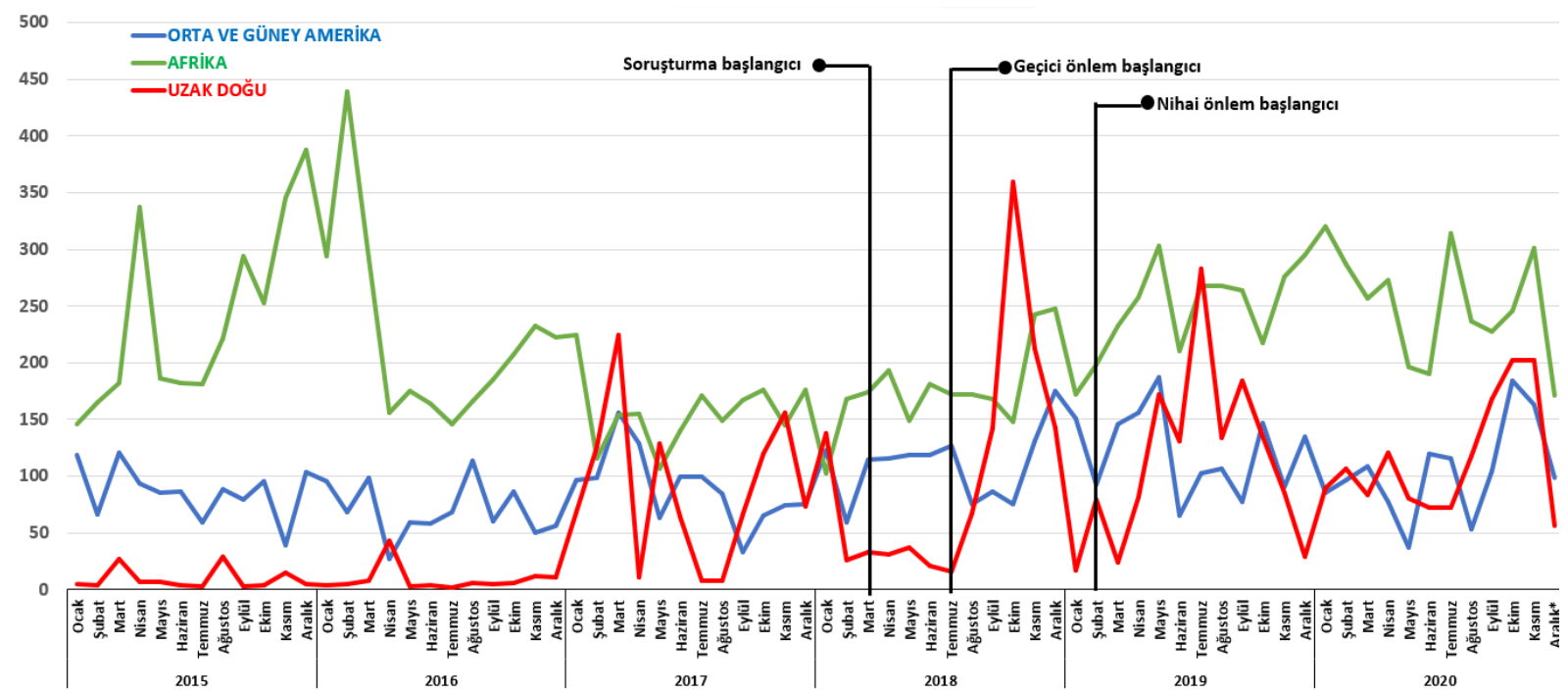

Kaynak: tim.org.tr verileri kullanılarak yazar tarafindan oluşturulmuştur.

2018 Temmuz ayında Avrupa Birliği Korunma Önlemi soruşturmasında geçici önlem başlangıcıyla birlikte Türkiye'nin Uzak Doğu'ya ihracatında artış yaşanmıştır. 2019 Şubat ayında nihai önlem başlangıcı ile Uzak Doğu'ya ihracat tekrar artış göstermiştir. AB'ye olan ihracat azaldığında Uzak Doğu'ya olan ihracatta da artış yaşandığı görülmektedir. Tam tersi için AB'ye olan ihracat arttı̆̆ında ise Uzak Doğu'ya olan ihracatta da azalış görülmektedir. 


\section{Sonuç}

ABD TPÖ araçları ile ana hedef olarak çelik üretimini canlandırmaya çalışmıştır. Alınan sonuçlara bakıldığında üretimin arttığı, kapasite kullanım oranının arttığı görülmektedir. Bu açıdan başarılı olduğu söylenebilir. Bunun yanı sıra ithalatta kayda değer düşüş olmuştur. Ancak, TPÖ sonucunda ürün fiyatlarında yükseliş olmuştur. Arz talep yapısı gereği, ABD ithalata ihtiyaç duyan bir ülke iken ithalatın kısıtlaması, iç piyasada fíyatların aşırı yükselmesi ve çelik kullanıcısı sektörlerin daha pahalı girdi maliyetlerine maruz kalmalarına yol açması gibi olumsuz sonuçlar doğurmuştur.

AB ise TPÖ araçları ile ithalattaki artışı engellemeyi amaçlamıştır. Bunun yanı sıra doğrudan vergi yerine kota uygulaması yapan $\mathrm{AB}$, fiyat artışları yaşamamıştır. $\mathrm{Bu}$ açılardan korunma önlemi uygulamasının başarılı olduğu görülmektedir. Ancak, $\mathrm{AB}$ çelik üretimi ve KKO açısından herhangi bir artış gözlenmemiştir. $\mathrm{Bu}$ sebeple $\mathrm{AB}$ çelik üreticileri korunma önleminin iç pazarı koruma açısından yetersiz kaldığını düşünmektedir.

Türk çelik sektörü söz konusu ticaret politikası önlemlerinden ve bu önlemlerin başlattığı küresel korumacılık trendinden özellikle son yıllarda ciddi şekilde etkilenmiştir. Dünya'nın hemen hemen her ülkesine çelik ihracatı gerçekleştiren Türkiye uzun yıllardır edindiği tecrübe ve deneyimle, geleneksel pazarlarında korumacılığın yol açtığı daralmalar yaşadığ çeşitlendirebilmiştir. Çelik sektörü ticaret politikası önlemleri sebebiyle alternatif pazarlara yönelmektedir. İthalatlarında Türkiye'nin payının az olduğu ve tüketimleri artma eğiliminde olan Latin Amerika, Batı Afrika ve Güneydoğu Asya bölgelerine olan ihracat artmaktadır.

Küresel ekonomi içinde her ülkenin hammadde, enerji, işgücü, lojistik, teknoloji gibi temel konularda kendine özgü rekabetçi avantajı bulunmaktadır. Ticaret politikası önlemlerinin, bu avantajları kullanarak ülkelerin serbest ticarette rekabeti bozacak hamlelerine karşı gerekli olduğu düşünülmektedir. Ancak, TPÖ uygulamalarının son dönemde olduğu gibi bir silah olarak kullanılmasının hem kullanan ülkelere hem de hedef olan ülkelere zarar verdiği düşünülmektedir.

\section{BEYANLAR}

Hakem Değerlendirmesi: Dış bağımsız.

Çıkar Çatışması: Yazar tarafından çıkar çatışması bildirilmemiştir.

Finansal Destek: Yazar bu çalışma için finansal destek almadığını beyan etmiştir. 


\section{KAYNAKÇA}

Aksoy, A. (2016). "Geleneksel devletten modern devlete: Sanayi devrimi ve kamu yönetimi düşüncesinde değişim”. Uluslararası Politik Araştırmalar Dergisi, 2(3).

Aslan, N. ve Yaman, A. (2020). “Türkiye'nin uluslararası ticarette uyguladığı ve karşılaştığı anti-damping vergileri üzerine bir inceleme”. İstanbul Gelişim Üniversitesi Sosyal Bilimler Dergisi, 7 (2), 238-256.

ArcelorMittal (2020). ArcelorMittal USA CEO testifies at Congressional Steel Caucus, https://usa.arcelormittal.com/news-and-media/announcements/2020/mar/brett-testimony (18.01.2021) Çelik İhracaţ̧ıları Birliği. (2021a). AB korunma önlemi soruşturmasında geçici önlem açıkladı. https://www.cib.org.tr/tr/cib-gundem-ab-korunma-onlemi-sorusturmasinda-gecici-onlem-acikladi.html (09.02.2021)

Çelik İhracatçıları Birliği. (2021b). Section 232 ürünleri. https://www.cib.org.tr/tr/cib-gundem-section-232urunleri.html (10.02.2021)

EUROFER. (2019). Press release: Crisis in steel industry, steel safeguard and cost of innovation key topics at European steel day 2019. https://www.eurofer.eu/assets/press-releases/crisis-in-steel-industry-steel-safeguardand-cost-of-innovation-key-topics-at-european-steel-day-2019/20190626-PRESS-RELEASE-European-SteelDay-2019.pdf (18.01.2021)

OECD. (2020). Latest developments in steelmaking capacity, June 2020. https://www.oecd.org/industry/ind/latestdevelopments-in-steelmaking-capacity-2020.pdf (09.02.2021).

T.C. Ekonomi Bakanlığı İhracat Gelen Müdürlüğü Pazara Giriş ve Uluslararası İlişkiler Daire Başkanlığı. (2015, 13 Mart). Türk ihraç ürünlerine yönelik ticaret politikası önlemleri. Kurum toplantısında yapılan sunum, Ankara. T.C. Ticaret Bakanlığı. (t.y.). Ticaret politikası savunma araçları. https://ticaret.gov.tr/ithalat/ticaret-politikasisavunma-araclari (09.02.2021)

https://dataweb.usitc.gov/scripts/user_set.asp (09.02.2021)

World Steel Association. (2021a). Global crude steel output decreases by $0.9 \%$ in 2020. https://www.worldsteel.org/media-centre/press-releases/2021/Global-crude-steel-output-decreases-by-0.9--in2020.html (08.02.2021)

World Steel Association. (2021b). Short range outlook october 2020. https://www.worldsteel.org/mediacentre/press-releases/2020/worldsteel-short-range-outlook-june-2020.html (08.02.2021) https://ec.europa.eu/eurostat/web/international-trade-in-goods/data/database (21.12.2020) https://stats.oecd.org/Index.aspx?datasetcode=STI_Section: Steelmaking Capacity (09.02.2021) https://tim.org.tr/tr/ihracat-rakamlari (08.01.2021) https://www.trademap.org/Index.aspx (05.01.2021) https://tr.steelorbis.com/celik-fiyatlari/haftalik-celik-fiyatlari/ (06.01.2021) $\underline{\text { https://data.worldbank.org/indicator/NY.GDP.MKTP.CD?locations=EU }}(09.02 .2021)$ 